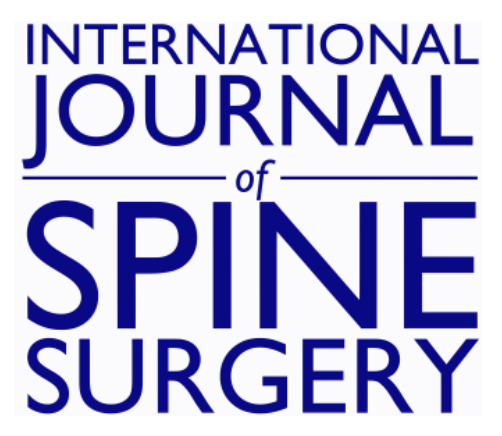

\title{
The Combined Use of a Posterior Dynamic Transpedicular Stabilization System and a Prosthetic Disc Nucleus Device in Treating Lumbar Degenerative Disc Disease With Disc Herniations
}

Mehdi Sasani, Ahmet Levent Aydin, Tunc Oktenoglu, Murat Cosar, Yaprak Ataker, Tuncay Kaner and Ali Fahir Ozer

Int J Spine Surg 2008, 2 (3) 130-136

doi: https://doi.org/10.1016/SASJ-2008-0008-NT

http://ijssurgery.com/content/2/3/130

This information is current as of April 26, 2023.

Email Alerts Receive free email-alerts when new articles cite this article. Sign up at: http://ijssurgery.com/alerts 


\title{
The Combined Use of a Posterior Dynamic Transpedicular Stabilization System and a Prosthetic Disc Nucleus Device in Treating Lumbar Degenerative Disc Disease With Disc Herniations
}

Mehdi Sasani, MD, ${ }^{a}$ Abmet Levent Aydin, MD, ${ }^{a}$ Tunc Oktenoglu, MD, ${ }^{a}$ Murat Cosar, MD, ${ }^{b}$ Yaprak Ataker, MD, ${ }^{c}$ Tuncay Kaner, $M D{ }^{d}$ and Ali Fahir Ozer, $M D^{a}$

\begin{abstract}
Background

Prosthetic replacement of spinal discs is emerging as a treatment option for degenerative disc disease. Posterior dynamic transpedicular stabilization (PDTS) and prosthetic disc nucleus (PDN) devices have been used sporadically in spinal surgery.

Methods

This was a prospective study of 13 patients averaging 40.9 years of age with degenerative disc disease who underwent posterior placement of a PDN with a PDTS. The Oswestry low-back pain disability questionnaire and visual analog scale (VAS) for pain were used to assess patient outcomes at the $3 \mathrm{rd}$, 6 th, and 12 th postoperative months.

Lumbar range of motion was evaluated using a bubble inclinometer preoperatively and at 12 months postoperatively. Radiological parameters including lumbar lordosis angle (LL), segmental lordosis angle $(\alpha)$, disc height at the operated level (DHo), and disc height of the adjacent level $(\mathrm{DHu})$ were evaluated. A typical midline posterior approach for complete discectomy was followed by the simultaneous placement of the PDN with PDTS.
\end{abstract}

Results

Both the Oswestry and VAS scores showed significant improvement postoperatively $(P<.05)$. There were no significant differences in LL, $\alpha, \mathrm{DHo}$, and DHu parameters. We observed complications in 3 patients including 2 patients who had the PDN device embedded into the adjacent corpus; 1 had massive endplate degeneration, and the other experienced interbody space infection. In 1 patient, the PDN device migrated to one side in the vertebral space.

\section{Conclusion}

The use of a PDN in combination with posterior dynamic instrumentation can help to restore the physiologic motion of the anterior and posterior column and could help to establish posterior dynamic instrumentation as an important treatment of degenerative disc disease. Theoretically this concept is superior, but practically we need more advanced technology to replace disc material. Because this study examined the combination of the PDN and stabilization instrumention, the results cannot be compared with those reported in the literature for either PDN alone or dynamic screws alone.

Level of Evidence

Prospective cohort study with good follow-up (level 1b).

Key Words: Dynamic instrumentation, prosthetic disc nucleus, degenerative disc disease, non fusion treatment, lumbar disc herniation. SAS Journal. Summer 2008;2:130-136. DOI: SASJ-2008-0008-NT

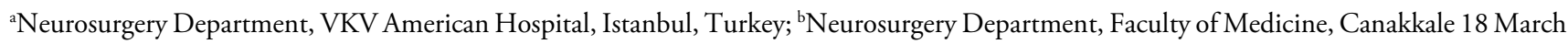

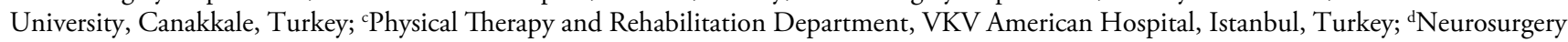
Department, Pendik State Hospital, Istanbul, Turkey

Address correspondence to Mehdi Sasani, MD, Neurosurgery Department, VKV American Hospital, Guzelbahce Sk. No: 20, 34365 Nisantasi, Istanbul, Turkey (email: sasanim@gmail.com)

The authors have no financial interest or other potential conflicts of interest to report in relation to the device used in this study.

\section{INTRODUCTION}

Prosthetic replacement of spinal discs is becoming a treatment option for degenerative disc disease, led by the success of hip and knee replacement. The prosthetic disc nucleus (PDN) device has been in clinical use in spine disc arthroplasty since 1996. This device is composed of a hydrogel core that can absorb fluid and expand when implanted and a polyethylene jacket. ${ }^{1}$ Similar to disc prostheses, the ideas behind the design of dynamic systems are to prevent devicerelated bone loss by allowing limited motion and to provide physiological loading by maintaining the natural posture in the lumbar spine. ${ }^{2}$ A dynamic pedicular screw hinge has monoaxial mobility capacity and provides controlled load sharing between implant and bone, reducing the frequency of postoperative damage to the joint segments. ${ }^{3}$ 
Table 1. Patients' Demographic Data

\begin{tabular}{|c|c|c|c|c|c|c|c|c|}
\hline $\begin{array}{l}\text { Patient } \\
\text { No. }\end{array}$ & Gender & Age & $\begin{array}{l}\text { Preoperative } \\
\text { Neurological } \\
\text { Findings }\end{array}$ & $\begin{array}{l}\text { Radiologic Findings } \\
\text { (X-Ray, CT, MRI) }\end{array}$ & Operation & $\begin{array}{l}\text { New/Recurrent } \\
\text { Disc Herniation }\end{array}$ & Complication & $\begin{array}{l}\text { Outcome } \\
\text { (12 months) }\end{array}$ \\
\hline 1 & $\mathrm{~F}$ & 26 & $\begin{array}{l}\text { - Right radiating } \\
\text { pain } \\
\text { - Right SLR: } 30^{\circ}+ \\
\text { - Right } \mathrm{S1} \text { nerve } \\
\text { root } \mathrm{DH} \\
\end{array}$ & $\begin{array}{l}\text { - L4-5: black disc } \\
\text { - L5-S1: central and right } \\
\text { disc extrusion }\end{array}$ & $\begin{array}{l}\text { - Right L5-S1 } \\
\text { discectomy + PDN } \\
\text { placement } \\
\text { - L4-L5-S1 PDTS }\end{array}$ & New disc & None & Improved \\
\hline 2 & $\mathrm{~F}$ & 40 & $\begin{array}{l}\text { - Left radiating pain } \\
\text { - Left SLR: } 10^{\circ}+ \\
\text { - Left gastrocne- } \\
\text { mius } 2 / 5 \mathrm{MW}\end{array}$ & $\begin{array}{l}\text { - L5-S1 disc sequestrated } \\
\text { - Both endplate hyperin- } \\
\text { tense }\end{array}$ & $\begin{array}{l}\text { - Left L5-S1 } \\
\text { discectomy + PDN } \\
\text { placement } \\
\text { - L5-S1 PDTS }\end{array}$ & New disc & None & Improved \\
\hline 3 & M & 57 & $\begin{array}{l}\text { - Right radiating } \\
\text { pain } \\
\text { - Right SLR: } 45^{\circ}+\end{array}$ & $\begin{array}{l}\text { - L5-S1 right disc extrusion, } \\
\text { - Right L5 hemilaminotomy } \\
\text { defect }\end{array}$ & $\begin{array}{l}\text { - Right L5-S1 } \\
\text { discectomy+ PDN } \\
\text { placement } \\
\text { - L5-S1 PDTS }\end{array}$ & Recurrent disc & $\begin{array}{l}\text { - Discitis, } \\
\text { - PDN device } \\
\text { embedded } \\
\text { into the L5 } \\
\text { corpus }\end{array}$ & $\begin{array}{l}\text { - Treatment: } \\
\text { antibiotic } \\
\text { administra- } \\
\text { tion, PDN was } \\
\text { removed } \\
\text { - LBP to } 3 \\
\text { months } \\
\text { - Late improved }\end{array}$ \\
\hline 5 & M & 38 & $\begin{array}{l}\text { - LBP } \\
\text { - Right radiating } \\
\text { pain }\end{array}$ & $\begin{array}{l}\text { - L5-S1 right disc protrusion } \\
\text { - Both endplates hyperin- } \\
\text { tense } \\
\text { - Right L5 hemilaminotomy } \\
\text { defect }\end{array}$ & $\begin{array}{l}\text { - Right L5-S1 } \\
\text { discectomy + PDN } \\
\text { placement } \\
\text { - L5-S1 PDTS }\end{array}$ & Recurrent disc & None & Improved \\
\hline 6 & M & 42 & $\begin{array}{l}\text { - LBP, left radiating } \\
\text { pain } \\
\text { - Left SLR: } 30^{\circ}+ \\
\text { - Left L5 nerve root } \\
\text { DH }\end{array}$ & $\begin{array}{l}\text { - L4-5: left protrusion } \\
\text { - Both endplates } \\
\text { hyperintense } \\
\text { - Left L4 hemilaminotomy } \\
\text { defect }\end{array}$ & $\begin{array}{l}\text { - Left L4-L5 } \\
\text { discectomy + PDN } \\
\text { placement } \\
\text { - L4-L5 PDTS }\end{array}$ & Recurrent disc & None & Improved \\
\hline 7 & M & 44 & $\begin{array}{l}\text { - Left radiating pain } \\
\text { - Left SLR: } 45^{\circ}+ \\
\text { - Left L5 nerve root } \\
\text { DH }\end{array}$ & - L4-5 left protrusion & $\begin{array}{l}\text { - Left L4-L5 } \\
\text { microdiscectomy } \\
\text { +PDN placement } \\
\text { - L4-L5 PDTS } \\
\end{array}$ & New disc & None & Improved \\
\hline 10 & M & 42 & $\begin{array}{l}\text { - Left leg radiating } \\
\text { pain } \\
\text { - Left SLR: } 45^{\circ}+\end{array}$ & - L4-5 left disc extrusion & $\begin{array}{l}\text { - Left L4-L5 } \\
\text { discectomy +PDN } \\
\text { placement } \\
\text { - L4-L5 PDTS }\end{array}$ & Recurrent disc & $\begin{array}{l}\text { PDN } \\
\text { embedded into } \\
\text { the L4 corpus } \\
\text { and massive } \\
\text { endplate } \\
\text { degeneration in } \\
\text { both endplates }\end{array}$ & $\begin{array}{l}\text { - PTR+ } \\
\text { conservative } \\
\text { treatment to } 3 \\
\text { months } \\
\text { - LBP to } 3 \\
\text { months } \\
\text { - Late improved }\end{array}$ \\
\hline 11 & M & 39 & $\begin{array}{l}\text { - Right leg radiat- } \\
\text { ing pain } \\
\text { - Right SLR: } 45^{\circ}+ \\
\text { - Right gastrocne- } \\
\text { mius } 2 / 5 \mathrm{MW}\end{array}$ & $\begin{array}{l}\text { - L5-S1 foraminal disc } \\
\text { protrusion }\end{array}$ & $\begin{array}{l}\text { - Right L5-S1 } \\
\text { discectomy +PDN } \\
\text { placement } \\
\text { - L5-S1 PDTS }\end{array}$ & New disc & None & Improved \\
\hline 12 & M & 45 & $\begin{array}{l}\text { - Left leg radiating } \\
\text { pain } \\
\text { - Left SLR: } 45^{\circ}+\end{array}$ & - L4-5 left disc extrusion & $\begin{array}{l}\text { - Left L4-L5 } \\
\text { discectomy +PDN } \\
\text { placement } \\
\text { - L4-L5 PDTS }\end{array}$ & New disc & None & Improved \\
\hline 13 & M & 40 & $\begin{array}{l}\text { - LBP } \\
\text { - Right radiating } \\
\text { pain }\end{array}$ & - L5-S1 right disc protrusion & $\begin{array}{l}\text { - Right L5-S1 } \\
\text { discectomy +PDN } \\
\text { placement } \\
\text { - L5-S1 PDTS }\end{array}$ & Recurrent disc & $\begin{array}{l}\text { PDN migrated } \\
\text { to right side in } \\
\text { the interverte- } \\
\text { bral space }\end{array}$ & Improved \\
\hline
\end{tabular}

SLR: Straight Leg Rising LBP: Lower back pain DH: Dermatome hypoesthesia PTR: Physical Treatment and Rehabilitation 
We evaluated 13 patients with primary ( 6 patients) and recurrent (7 patients) degenerative lumbar disease who received a PDN combined with posterior dynamic transpedicular stabilization (PDTS). The basic concept of this procedure was to create simultaneous anterior and posterior column stability to control the movement that occurs in the anterior and posterior column using PDTS, while at the same time supporting the height of the anterior column with the PDN.

\section{MATERIALS AND METHODS}

\section{Patient Population}

Thirteen patients, averaging 40.9 years of age, presented with 6 primary cases and 7 recurrent lumbar disc herniations. They underwent the simultaneous application of a PDN and PDTS (Table 1). Patients' outcomes were followed for 12 postoperative months using the visual analog scale (VAS) for pain, which ranges from 0 (no pain) to 10 (worst pain imaginable) and the Oswestry Disability Index, a questionnaire comprised of 10 items designed to assess daily living activities that are most likely to be impaired in patients with low-back pain; a high Oswestry Disability Index percentage indicates high disability. ${ }^{4,5,6}$

Lumbar range of motion was evaluated by the bubble inclinometer technique as described by Mayer et al. in $1984 .^{7}$

Radiological evaluations prior to and after surgery consisted of anteroposterior (AP) and lateral X-rays, computed tomography (CT), and magnetic resonance (MR) studies. The heights of the operated disc (DHo) and superior disc (DHu), segmental lordotic angles $(\alpha)$, and lumbar lordosis angle (LL) were used to evaluate patients' outcomes (Figure 1, Table 2).

\section{Figure 1.}

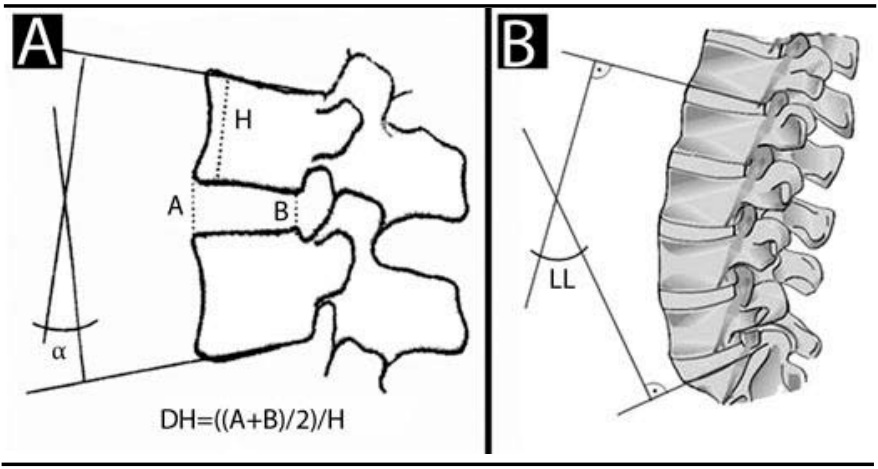

A schematic calculation: (A) A ratio of disc height and segmental lordosis angle ( $\alpha$ angle) for the upper adjacent segment was calculated pre- and postoperatively. (B) Measurement of lordosis of the lumbar spine L1 to S1 was calculated.

\section{Surgical Technique}

A typical midline dorsal approach for complete 1-level lumbar discectomy was followed by the simultaneous placement of the PDN with dynamic pedicles screw/rod placement under

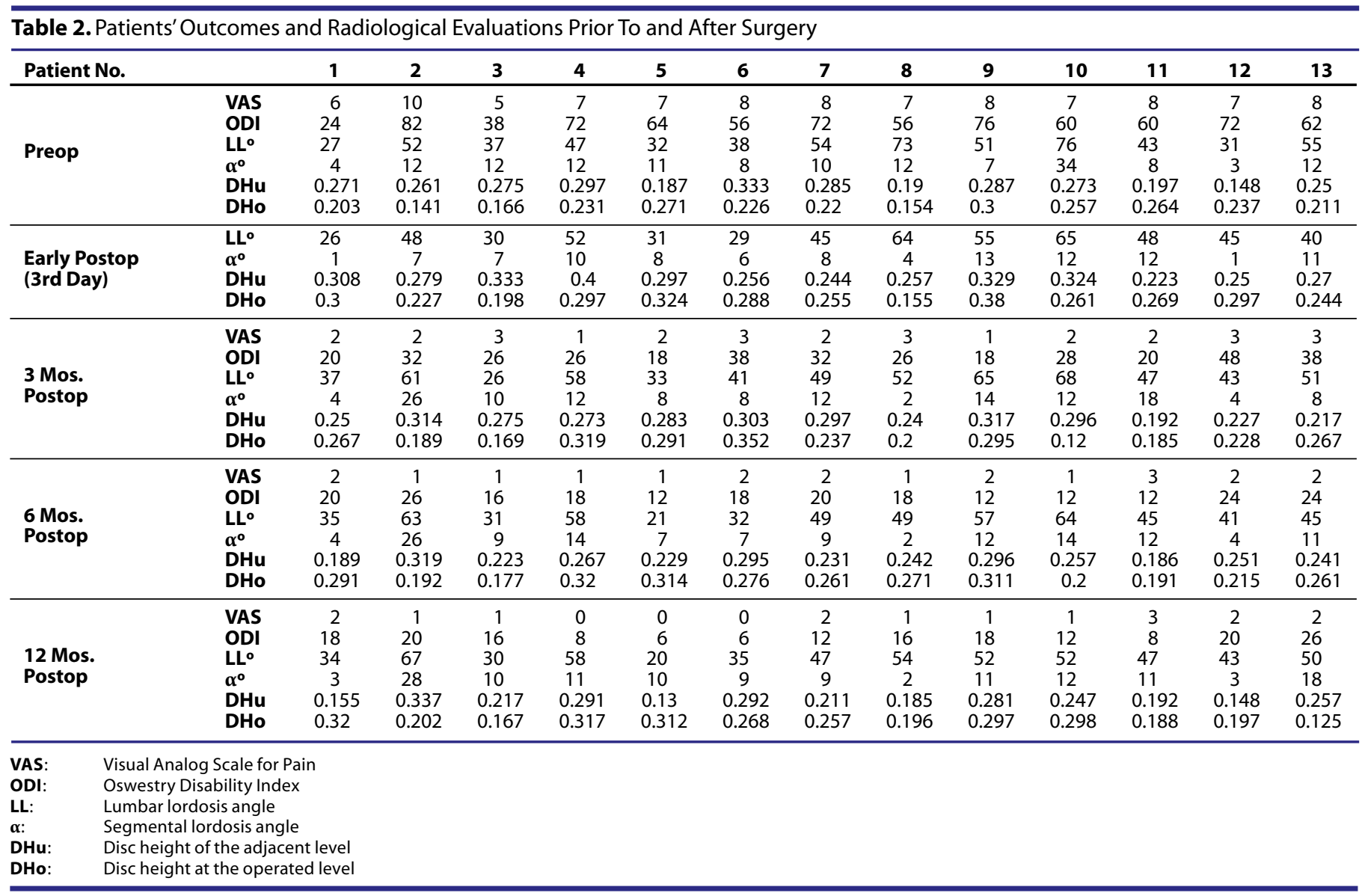


fluoroscopy (Figure 2). Each patient was operated on by the same experienced spine surgeon. During the operation, patients were under general anesthesia in a prone position and received antibiotic prophylaxis for at least 48 hours. A midline incision was performed, and the affected segments were exposed by subperiosteal muscle dissection. Under an operation microscope, ligamentum flavum excision, dura exposure, and a total nucleotomy were performed on each side. The facet joints were preserved during nucleotomy.

\section{Figure 2.}

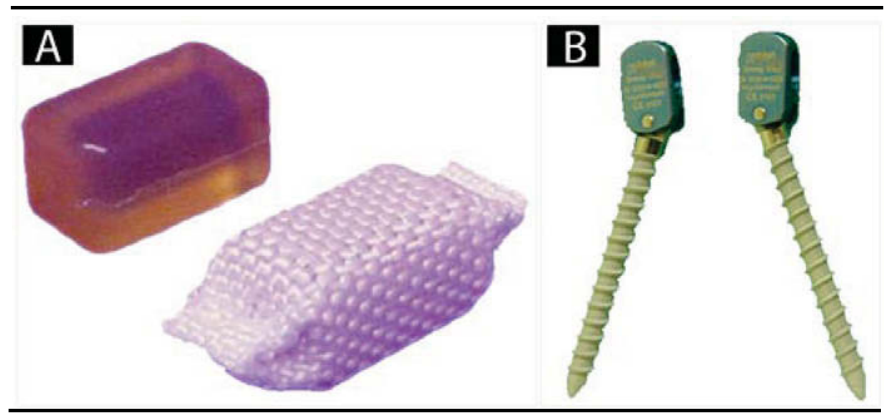

(A) Prosthetic disc nucleus (PDN-Solo, Raymedica, LLC) devices. (B) Titanium alloy Cosmic (Ulrich Gmbh \& Co. KG, Ulm, Germany) dynamic pedicle screw.

Following the discectomy, the prosthetic disc nucleus devices (PDN-Solo, Raymedica, LLC, Minneapolis, Minnesota) were placed under microscope, and their positions were controlled by fluoroscopy. Afterwards, under fluoroscopy, the titanium alloy pedicle screws (Cosmic, Ulrich Gmbh \& Co. KG, Ulm, Germany) were inserted. The screws were then connected with titanium alloy rods under optimum compression. Then, a deep drainage catheter was inserted, and the fascia was carefully closed. The wound was closed and all patients were mobilized within the next day of the operation without a brace.

\section{Statistical Methods}

The preoperative versus postoperative clinical findings (VAS, Oswestry scale) were compared using the Wilcoxon test.

\section{RESULTS}

The averages of obtained data are summarized in Table 3. The average Oswestry (improved $46.78+$ points) and VAS (improved $6.15+$ points) scores demonstrated improvement over the first postoperative year $(P<.05)$. The averages of DHo and DHu pre- and post-operatively showed an increase $(0.02+$ points $)$ and decrease $(0.03+$ points $)$, respectively $(P>$ $.05)$. The average LL and $\alpha$ angles showed decreases $\left(2.08^{\circ}\right.$ and $0.62^{\circ}$, respectively) over the first postoperative year $(P$ $>.05)$.

The Oswestry score showed significant improvement from the preoperative exam to the third postoperative month $(P$ $<.05)$. This improvement was stable at the 6- and 12-month exams. The VAS showed significant pain reduction after the operation $(P<.05)$, and improved during the following 6 and 12 months. The postoperative radiologic evaluation showed a central position for all PDN devices, except in 1 patient (patient \#13), and proper position of the implanted pedicle screws (Figure 3).

Table 3. Averages of Preoperative and Postoperative Data Points

\begin{tabular}{|c|c|c|c|c|c|c|c|}
\hline & VAS & ODI & LLo & $\alpha^{\circ}$ & DHu & DHo \\
\hline \multicolumn{2}{|c|}{ Preoperative } & 7.38 & 61.08 & 47.38 & 11.15 & 0.25 & 0.22 \\
\hline \multicolumn{2}{|c|}{$\begin{array}{l}\text { Early } \\
\text { Postoperative } \\
\text { (3rd day) }\end{array}$} & 6.82 & ---- & 44.46 & 7.69 & 0.29 & 0.27 \\
\hline \multicolumn{2}{|c|}{$\begin{array}{l}3 \text { Month } \\
\text { Follow-up }\end{array}$} & 2.23 & 28.46 & 48.53 & 10.61 & 0.26 & 0.23 \\
\hline \multicolumn{2}{|c|}{$\begin{array}{l}6 \text { Month } \\
\text { Follow-up }\end{array}$} & 1.61 & 17.84 & 45.38 & 10.07 & 0.24 & 0.25 \\
\hline \multicolumn{2}{|c|}{$\begin{array}{l}12 \text { Month } \\
\text { Follow-up }\end{array}$} & 1.23 & 14.30 & 45.30 & 10.53 & 0.22 & 0.24 \\
\hline $\begin{array}{l}\text { VAS: } \\
\text { ODI: } \\
\text { LL: } \\
\text { Q: } \\
\text { DHu: } \\
\text { DHo: }\end{array}$ & \multicolumn{3}{|c|}{$\begin{array}{l}\text { Visual analog scale for pain } \\
\text { Oswestry Disability Index } \\
\text { Lumbar lordosis angle } \\
\text { Segmental lordosis angle } \\
\text { Disc height of the adjacent level } \\
\text { Disc height at the operated level }\end{array}$} & & & & \\
\hline
\end{tabular}

\section{Figure 3.}

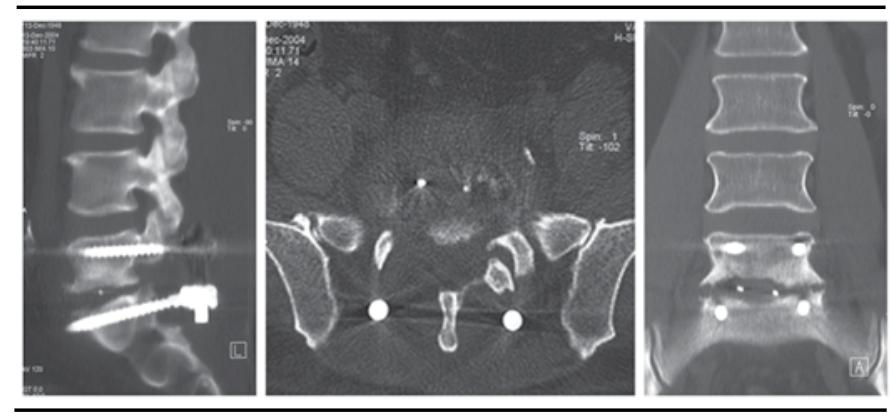

A postoperative lumbar CT scan showing the central position of the PDN device and proper position of the implanted pedicle screws.

The Oswestry and VAS scores showed significant improvements at 3, 6, and 12 months postoperatively. There were no significant differences between any of the 4 measured radiologic parameters within the first postoperative year.

Range of motion was measured in all patients. There were no significant differences between preoperative and 12-month postoperative range of motion values $(P>.05)$ (Table 4$)$.

We observed postoperative complications in 3 patients. In 2 patients (patients \#3 and \#10) the PDN device embedded into the adjacent corpus. Patient \#3 developed an interbody space infection, and patient \#10 had massive endplate degeneration. In a third patient (\#13) the PDN device migrated to one side in the intervertebral space (Figure 4).

None of the patients showed significant intervertebral space height reduction at the operated level (DHo), except in the cases of embedded PDN. In these 2 cases, severe inflammatory reactions occurred with loading disc height in adjacent 
vertebrae (Figure 4). We can accept these changes as early findings of Modic degeneration. The intervertebral spaces at the upper adjacent levels did not change significantly in any of the patients.

Table 4. Preoperative And Postoperative 12-month Range of Motion Values

\begin{tabular}{ccccc}
\hline Patient & $\begin{array}{c}\text { Preop } \\
\text { Flexion }\end{array}$ & $\begin{array}{c}\text { 12-month } \\
\text { Postop } \\
\text { Flexion }\end{array}$ & $\begin{array}{c}\text { Preop } \\
\text { Extension }\end{array}$ & $\begin{array}{c}\text { 12-month } \\
\text { Postop } \\
\text { Extension }\end{array}$ \\
\hline 1 & 48 & 53 & 15 & 18 \\
2 & 43 & 47 & 13 & 15 \\
3 & 35 & 38 & 11 & 15 \\
4 & 62 & 64 & 16 & 23 \\
5 & 45 & 50 & 11 & 15 \\
6 & 51 & 53 & 15 & 17 \\
7 & 45 & 49 & 14 & 18 \\
8 & 56 & 58 & 18 & 24 \\
9 & 41 & 47 & 10 & 13 \\
10 & 45 & 50 & 16 & 22 \\
11 & 53 & 58 & 14 & 20 \\
12 & 52 & 55 & 16 & 19 \\
13 & 45 & 49 & 17 & 19 \\
Mean: & 47.76923 & 51.61538 & 14.30769 & 18.30769 \\
\hline
\end{tabular}

\section{Figure 4.}

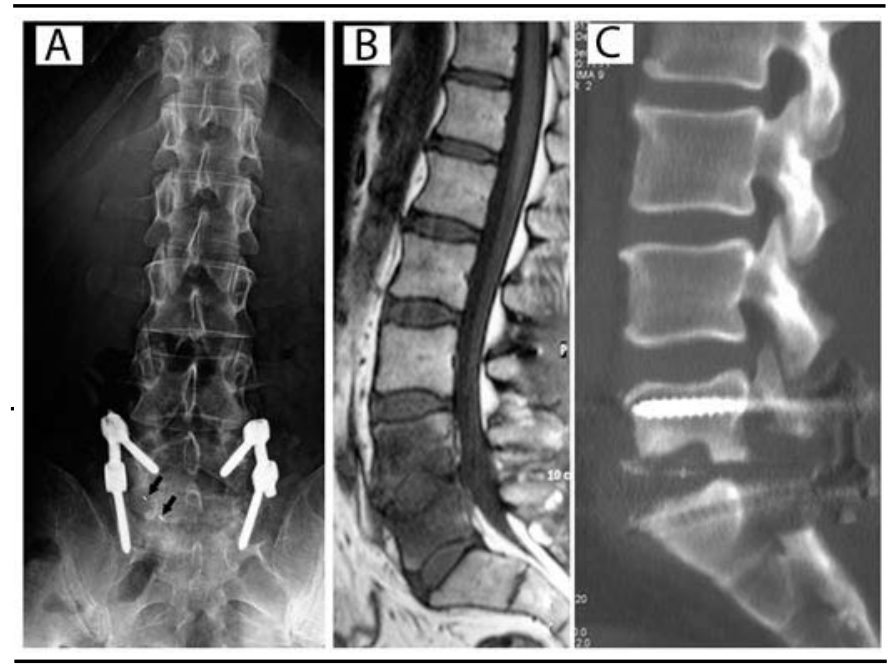

Postoperative complications: (A) A plain $\mathrm{X}$-ray shows the device has migrated to lateral interspace vertebra (patient \#13). (B) A T1-weighted sagittal MRI demonstrates that the PDN-Solo device has become embedded in the adjacent vertebra with massive degeneration at both endplate vertebral bones (patient \#10). (C) A sagittal CT shows the PDN-Solo device has become embedded in the adjacent vertebra in a patient with discitis (patient \#3).

\section{DISCUSSION}

Spinal instability caused by degenerative changes in the disc with subsequent spondylolisthesis, ankylosis, and neuroforaminal stenosis may induce back pain. ${ }^{2}$ From among the causes of spinal instability, degenerative disc disease (with its characteristic clinical syndromes of disc herniation, spondylosis, and radiculopathy) is associated with vascular, biomechanical, and anatomic changes in the disc.

For many decades, stabilization, intended to fix the abnormal movement of the spine, has become the treatment of choice for instability. The goal of fusion was to provide motion stability in arthrodesis and deformity correction, thus controlling and even strengthening the movement of the segment. ${ }^{8}$ However, good fusion rates are not correlated with the clinical relief of the patient's back pain symptoms. The best results measured by different clinical scales show around $30 \%$ of suboptimal healing after instrumented fusion surgery despite a fusion rate of more than $90 \% .{ }^{9}$ Many authors reported adjacent segment degeneration following lumbar and lumbosacral fusion with rigid instrumentation. ${ }^{10}$ Kumar et al. described degenerative changes in $49 \%$ of patients after 5 years of follow-up. ${ }^{11}$ Because of these problems, less rigid stabilization systems have recently become more popular in spine surgery.

The PDN device has been in clinical application since 1996. It was developed by Charles D. Ray. This device is composed of a hydrogel core that can absorb fluid and expand when implanted. ${ }^{1}$ The hydrogel core is covered with a polyethylene jacket. The core and the jacket are designed to assume the cushioning function of a healthy disc, while restoring and maintaining disc height and allowing a normal range of motion. The high-tenacity polyethylene jacket allows the device to absorb fluid, expanding only in height. This expansion restores disc height to relieve pressure on the spinal nerves. Biomechanical studies using a human cadaver model showed that PDN can effectively increase the heights of the intervertebral discs. ${ }^{12}$ However, clinical observations showed us that in some cases the PDN, when used alone, slips to one side of the midline in the disc space.

Another promising system is the dynamic pedicular screwrod system. It is a non-fusion dynamic implant system that controls displacement in rotation and translation. It stabilizes while avoiding fusion. This system allows potential sagittal mobility at the hinge site between the screw head and the shank of the screw. Mobility occurs mechanically between the longitudinally oriented rod and the sagittally placed screw shank. This articulated connection between the rod and the screw is the reason for the lower rate of implant failure, because of a reduction in flexion strain. Part of the load sharing is transferred from the implant to the spine, ie, there is a reduction of stress-shielding effects on the bone. ${ }^{13}$ This reduced stiffness helps distribute load and minimize or prevent a motion discontinuity at the adjacent segment. Sharing of motion and stress load prevents deterioration of the neighboring superior disc level, slowing the process of degenerative progression at the adjacent levels, and tends to restrict mobility in flexion, extension, lateral bending, and axial rotation while sharing load and permitting movement. ${ }^{14}$ Also, the capability of a controlled load sharing between the 
implant and spine could reduce the frequency of postoperative damage to the joint segments.

The indication for PDN application is painful degeneration of the lumbar spinal disc, which has become sufficiently disabling despite 6 months of conservative medical care, rest, exercise, change in lifestyle, etc. The contraindications for PDN device use are spondylolisthesis greater than grade I, fractured or symptomatic degenerated facet joints, an incompetent annulus, or disc height at the affected level of $<5 \mathrm{~mm}$. These criteria are all based largely on the history, examination, MRI, and, perhaps, provocative discography. 1 Also, the vertebral endplates must be free of significant defects such as Schmorl's nodules or fractures before PDN application. ${ }^{15}$ In our patient group, these features were taken into consideration for PDN application.

Dynamic stabilization using a hinged screw allows motion of disc and facet joints because of the hinged line just posterior to the facet joints. In contrast, posterior dynamic stabilization transfers the load through the posterior column and stabilizes the spine almost like a rigid stabilization technique, preserving motion.3 Preservation of motion makes this technique useful for conditions where PDN use might be contraindicated, such as degenerative spondylolisthesis. As a result, the use of these 2 instruments together minimizes their disadvantages and restores both anterior and posterior columns.

In this limited series, we observed slippage of PDN in 2 cases. However, slippage of PDN with Modic degeneration of adjacent vertebrae is consistent with findings in the literature related to the use of a standalone PDN. On the other hand, in 2 other cases we noticed severe inflammation of adjacent vertebrae due to fracture of upper and lower endplates. In these cases, the PDN was embedded into the upper and lower vertebrae. Surprisingly, there were no clinical symptomatic or neurologic findings in these cases.

We assumed that large size of the PDN device due to the excessively stiff high-tenacity polyethylene jacket enclosing the polymeric hydrogel caused the fracture of endplates, which then made contact with cartilage tissue and blood, provoking an immune response, and resulting in massive degeneration of the vertebral bone. ${ }^{16}$ On the other hand, the hydrolysis time of 3 weeks was too long; therefore a rigid material between the 2 vertebral corpuses carries the risk of fracture of the cartilaginous endplates.

Dynamic stabilization systems without fusion and PDN devices have been used sporadically in spinal surgery. Ideally, semi-rigid implants dedicated to dynamic stabilization should control movement and share the load with the disc. Constraining the movement of the dynamic screw is more for providing adequate stability and mobility of the segment, and has less to do with avoiding the hot spot pressure on the disc.

The reasons for using the dynamic screw system in combination with PDN are to restore and preserve the disc height with the PDN device, while providing dynamic transpedicular stabilization with the screw system.

Although the VAS and Oswestry scores were satisfactory in our limited series of patients, for those with migrated PDN and infection, we thought that we could eliminate the migration complication with the use of posterior dynamic stabilization. However, we could not. The surprising result was that we saw cartilaginous endplate fracture due to the PDN and associated infection findings on MR studies, but the clinical outcome was not negatively affected.

PDN alone is not soft enough to resemble disc tissue. More appropriate material resembling disc tissue should be developed, and a more dynamic posterior system will need to be found. Theoretically, this concept is superior, but practically we need more advanced technology.

Because this study examined the combination of the PDN and stabilization instrumention, the results cannot be compared with those reported in the literature for either PDN alone or dynamic screws alone.

This manuscript was submitted May 30, 2008, and accepted for publication July 24, 2008.

\section{REFERENCES}

1. Jin D, Qu D, Zhao L, Chen J, Jiang J. Prosthetic disc nucleus (PDN) replacement for lumbar disc herniation: preliminary report with six months' follow-up. J Spinal Disord Tech. 2003;16(4):331-337.

2. Inceoglu S. Posterior Dynamic Stabilization of the Lumbar Spine. World Spine J. 2006;1(2):62-67.

3. Bozkus H, Senoglu M, Ozer AF, Sonntag VK, Crawford NR. Comparative stabilization properties of rigid and hinged-dynamic pedicle screw fixation techniques.(Unpublished data results)

4. Jensen MP, McFarland CA. Increasing the reliability and validity of pain intensity measurement in chronic pain patients. Pain. 1993;55(2):195203.

5. Baker D, Pynsent P, Fairbank J. The Oswestry Disability Index revisited. In: Roland M; Jenner J; eds. Back Pain: New Approaches to Rehabilitation and Education. Manchester, UK: Manchester University Press; 1989:174-186.

6. Fairbank JCT, Pynsent PB. The Oswestry Disability Index. Spine. 2000;25(22): 2940-2952.

7. Mayer TG, Tencer AF, Kristoferson S, Mooney V. Use of noninvasive techniques for quantification of spinal range-of-motion in normal subjects and chronic low-back dysfunction patients. Spine. 1984;9(6):588-595.

8. McNally DS. The objectives for the mechanical evaluation of spinal instrumentation have changed. Eur Spine J. 2002;11(2 Suppl):S179185.

9. Mulholland RC, Sengupta DK. Rationale, principles and experimental evaluation of the concept of stabilization. Eur Spine J. 2002;11(2 Suppl):S198-205. 
10. Hilibrand AS, Robbins M. Adjacent segment degeneration and adjacent segment disease: the consequences of spinal fusion? Spine J. 2004;4(6 Suppl):190S-194S.

11. Kumar MN, Baklanov A, Chopin D. Correlation between sagittal plane changes and adjacent segment degeneration following lumbar spine fusion. Eur Spine J. 2001;10(4):314-319.

12. Eysel P, Rompe JD, Schoenmayr R, Zoellner J. Biomechanical behaviour of a prosthetic lumbar nucleus. Acta Neurochir (Wien). 1999;141(10):1083-1087.

13. Strempel A, Neekritz A, Muelenaere P, et al. Dynamic versus rigid spinal implants. In: Gunzburg R, Szpalski M, eds. Lumbar Spinal Stenosis. Philadelphia: Lippincott-Williams and Wilkins; 2000:275-285.

14. Putzier M, Schneider SV, Funk JF, Tohtz SW, Perka C. The surgical treatment of the lumbar disc prolapse: nucleotomy with additional transpedicular dynamic stabilization versus nucleotomy alone. Spine. 2005;30(5):E109-114.

15. Ray CD. The PDN prosthetic disc-nucleus device. Eur Spine J. 2002;11(2 Suppl):S137-142.

16. Bogduk N. The innervation of intervertebral discs. In: Ghosh P, ed. The Biology of the Intervertebral Disc. Volume 1. Boca Raton, FL: CRC Press; 1988:135-149. 